\title{
Erratum to inhibition of IL-6/JAK/STAT3 pathway rescues denervation-induced skeletal muscle atrophy
}

\section{Editorial Office}

Annals of Translational Medicine

Correspondence to: Editorial Office. Annals of Translational Medicine. Email: editor@atmjournal.org.

doi: 10.21037/atm-2021-3

View this article at: http://dx.doi.org/10.21037/atm-2021-3

Erratum to: Ann Transl Med 2020;8:1681

In the article published in the Vol. 8, No 24 issue of Annals of Translational Medicine (1), the Laminin dyeing pictures of Ctrl and Den group in Figure 6A were placed incorrectly, and the correct version of Figure 6A is attached as below.

Click here to view the updated version of the article.
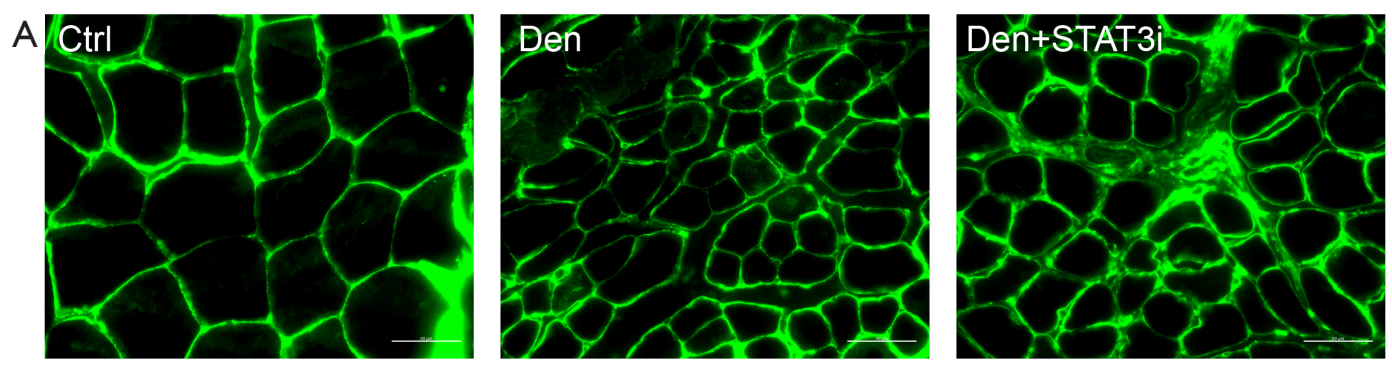

Open Access Statement: This is an Open Access article distributed in accordance with the Creative Commons AttributionNonCommercial-NoDerivs 4.0 International License (CC BY-NC-ND 4.0), which permits the non-commercial replication and distribution of the article with the strict proviso that no changes or edits are made and the original work is properly cited (including links to both the formal publication through the relevant DOI and the license). See: https://creativecommons.org/licenses/by-ncnd/4.0/.

\section{References}

1. Huang Z, Zhong L, Zhu J, et al. Inhibition of IL-6/JAK/STAT3 pathway rescues denervation-induced skeletal muscle atrophy. Ann Transl Med 2020;8:1681.

Cite this article as: Editorial Office. Erratum to inhibition of IL-6/JAK/STAT3 pathway rescues denervation-induced skeletal muscle atrophy. Ann Transl Med 2021;9(9):826. doi: 10.21037/ atm-2021-3 